\title{
Psikoetnografi sebagai metode asesmen psikologi komunitas
}

\author{
Retno Hanggarani Ninin*, Noer Fauzi Rachman, Karolina Lamtiur Dalimunthe, \\ Asysyifa Rakhmadevi, Hammad Zahid Muharram, Sitti Muthia Maghfirah Massinai, \\ Syifa Adilla, \& Yunita Anggraeni \\ Fakultas Psikologi, Universitas Padjadjaran, Bandung,Jawa Barat
}

\begin{abstract}
Abstrak
Meskipun ilmu tentang asesmen sebagai pengukuran berkembang pesat di bidang psikologi, namun as esmen psikologi di arena alamiah (natural setting) masih belum banyak dibahas, dibandingkan dengan pembahasan tentang asesmen dan pengukuran psikologi di setting khusus seperti di ruang klinik dan industriDiperlukan suatu metode asesmen yang menjadikan komunitas bukan hanya sebagai tempat munculnya perilaku, melainkan sebagai modalitas yang menjadi bagian dari perilaku. Memanfaatkan keilmuan psikologi komunitas, dan etnografi, studi ini mengeksplorasi potensi etnografi sebagai instrumen untuk asesmen psikologi di setting alamiah. Kami memberikan contoh riset yang kami lakukan untuk menggambarkan pendekatan psikoetnografi. Riset tindakan dipilih sebagai pendekatan, dengan memanfaatkan mata kuliah etnografi yang diselenggarakan di program pasca sarjana psikologi. Tiga dosen dan lima mahasiswa peserta mata kuliah tersebut adalah tim peneliti, tiga lokasi dipilih, dan para mahasiswa belajar metode dan contoh-contoh etnografi di kelas, lalu mempraktekkan etnografi. Data yang dihasil kan berupa catatan etnografi, logbook kegiatan lapangan, dan laporan dalam format makalah, selanjutnya diperlakukan sebagai data asesmen yang akan diinterpretasikan aspek psikologisnya. Interpretasi yang dilakukan menunjukkan kemampuan etnografi untuk menghasilkan data psikologis yang dibutuhkan untuk asesmen psikologi. Dengan demikian, psikoetnografi dapat dipertimbangkan sebagai alat kerja psikolog untuk melakukan asesmen psikologi pada sekelompok individu di setting komunitas sebagai lingkungan naturalnya.
\end{abstract}

Kata kunci: etnografi, psikoetnografi, psikologi komunitas, asesmen psikologi.

\begin{abstract}
Although the science of assessment as a measure has rapidly developed and well-discussed in the field of psychology, psychological assessments in natural social settings are much less discussed. Psychoethnography, is a promising form of a measure in a natural social context. This study explores ethnography as an instrument for psychological assessment in natural settings. We provide an example from our action research to give a better understanding of such approach. Here, we evaluated the ethnographic courses held at the post-graduate psychology program. The students studied ethnographic methods and provided examples in the classroom, and in turn, practiced the ethnography in an action setting. The data generated in the form of ethnographic records, logbook field activities, and reports, were then treated as data assessment to be interpreted psychologically. Interpretation is performed to demonstrate the ethnographic ability to produce psychological data needed for psy chological assessment Thus, psychoethnography can be considered as a tool of psychologists to conduct psychological assessment of the group of individuals in the community setting.
\end{abstract}

Keywords: ethnography, psychoethnography, community psychology, psychological assessment

\section{Pendahuluan}

Etnografi adalah metode pengumpulan data yang berakar dan lazim digunakan di bidang antropologi dan sosiologi (Newman \& Benz, 1998), dan seringkali dikaitkan dengan kebutuhan untuk mendapatkan makna tentang suatu fenomena (Biddle \& Locke, 2007) dan budaya (Bartholomew \& Brown, 2019).

Naskah masuk: 6 Februari 2020

Naskah diterima: 28 Juli 2020
Meskipun etnografi banyak dikenal sebagai metode untuk meneliti budaya, peneliti budaya sendiri ada yang menganggap etnografi lebih sebagai seni daripada ilmiah (Slay, 2007). Di bidang psikologi, metode kualitatif mulai diterima di American Psychological Association (APA) pada tahun 2014, sebagai salah satu unit di bawah divisi 5 , sekaligus ditandai dengan perubahan nama divisi dari semula 
bernama Division of Evaluation, Measurement, and Statistics, menjadi Quantitative and Qualitative Methods, membutuhkan waktu sembilan tahun sejak diusulkan pertama kali ke APA di tahun 2005 (Josselson, 2020). Khusus metode etnografi, meskipun masih memunculkan perdebatan terkait kelayakan dari sisi ilmiahnya (Nerlich, 2004), tetapi terdapat sepuluh artikel dengan kata kunci 'ethnography' di seluruh jurnal di bawah APA antara tahun 2004 sampai dengan 2018 (APA, 2020). Bartholomeuw dan Brown (2019) menjelaskan bahwa psikologi arus utama yang cenderung berfokus pada penemuan teori-teori atau hukum-hukum universal atas perilaku, lebih menyukai pendekatan eksperimen yang mengisolasi perilaku dari konteks dan budayanya serta hanya berfokus untuk melihat peran suatu variabel terhadap perilaku, dibandingkan dengan melibatkan budaya sebagai konteks di mana proses psikologis dan perilaku terjadi.

Padahal, seringkali konteks alamiah bisa sangat berbeda dengan konteks laboratorium eksperimen. Apalagi jika kita memperhitungkan persoalan konteks alamiah dari budaya yang berbedabeda. Bisa jadi, masalah krisis replikasi dalam ilmu psikologi belakangan ini disebabkan juga oleh konteks alamiah yang berbeda dalam pengujian replikasi (Stroebe \& Strack, 2014). Sehingga, kita perlu mengeksplorasi psikis manusia dari berbagai kebudayaan terutama dalam konteks alamiah dimana mereka berada. Tanpanya, psikologi berisiko hanya cenderung menggeneralisasi temuan laboratorium sementara minim kontribusi untuk menyelesaikan permasalahan di berbagai konteks.

\section{Etnografi sebagai metode asesmen yang potensial}

Para psikolog komunitas adalah kelompok praktisi di dalam APA yang paling sering menggunakan etnografi, dengan tujuan untuk memahami terjadinya perkembangan, perubahan sosial, tindakan sosial, pemaknaan mendalam dan mengidentifikasi peran komunitas terhadap faset-faset psikologis (Bartholomew \& Brown, 2019), serta menciptakan perubahan sosial (Case, Todd, \& Kral, 2014). Etnografi digunakan ketika pemangku kepentingan atas suatu komunitas merencanakan intervensi sosial yang berorientasi pada perubahan sosial, menggunakan pendekatan kolaboratif dengan mempertimbangkan budaya dan konteks yang melekat pada komunitas tersebut, serta melibatkan anggota komunitas sebagaimana praktek yang dilakukan di Singapura (Department of Communi-cation and New Media, Faculty of Arts and Social Sciences, National University of Singapore, 2016) dan Burma (Thein-Lamelson, 2015).

Dalam ruang kerja profesional psikolog asesmen psikologi ditujukan untuk memahami kondisi klien atau subjek. Jurnal APA yaitu Psychological Assessment memfokuskan jurnalnya pada riset empiris yang relevan dengan asesmen di setting psikologi klinis (APA, 2020). Meyer, dkk (2001) menggarisbawahi tujuan asesmen psikologi yang utama, yaitu menggambarkan kapasitas dan pemfungsian psikologis termasuk kemungkinan gangguan, mengonfirmasi dan memodifikasi kesan yang terbentuk melalui interaksi tak terstruktur dengan pasien, serta mengidentifikasi kebutuhan terapi. Penggunaan terminologi "gangguan", "pasien", dan "terapi" tersebut mengisyaratkan as esmen sebagai suatu kegiatan yang dilakukan di arena (setting) klinis dan ranah kesehatan. Terminologi "riset empiris" yang terdapat dalam cakupan jurnal Psychological Assessment di atas menunjukkan bahwa dal am asesmen terdapat aktivitas riset.

Riset empiris dalam konteks asesmen melibatkan penerapan berbagai metode pengukuran, serta menganalisis data hasil pengukuran dalam konteks a) kronologis waktu (sejarah), b) informasi pihak lain yang terkait, serta c) observasi terhadap tingkah laku, guna a) memahami individu, b) menjawab pertanyaan pihak terkait, dan c) mengomunikasikan hasil analisisnya kepada pasien, orangorang penting bagi pasien tersebut, dan pihak lain yang relevan (Meyer, dkk., 2001). Dengan proses dan tujuan yang serupa, etnografi sebagai suatu metode riset dapat diposisikan sebagai metode pengukuran untuk tujuan asesmen psikologi di arena komunitas.

Etnografi yaitu proses memahami suatu fenomena yang terjadi pada sekelompok orang melalui orang yang mengalaminya (Bartholomew \& Brown, 2019), dengan melibatkan berbagai teknik perolehan data. Teknik yang lazim digunakan dalam etnografi antara lain observasi partisipatif dan nonpartisipatif, wawancara individual dan kelompok, percakapan informal, catatan harian, dokumentasi visual, refleksi, dan naturalistic inquiry (Madill \& Gough, 2008), in-person observations dan informal interviews (Hallett \& Barber, 2014), serta wawancara, diskusi kelompok, dan analisis dokumen (Case, Todd, \& Kral, 2014). Selain teknik-teknik di atas, etnografi juga berpeluang dikembangkan menjadi suatu metode dan teknik yang lebih spesifik dalam pengumpulan data seperti yang dilakukan oleh Lahlou, Le Bellu \& Boesen-Mariani (2015) yang memakai Subjective Evidence Based Ethnography (SEBE) untuk menggali know-how dari perspektif orang pertama.

Oleh karena teknik-teknik dalam etnografi ditujukan antara lain untuk mendapatkan data tentang keyakinan (beliefs), interaksi sosial, dan behaviours of small societies (Naidoo, 2012), maka etnografi dapat memenuhi fungsi seperti yang diemban oleh wawancara, observasi, dan tes psikologi dalam asesmen psikologi di arena klinis. Tidak hanya itu, sejumlah riset etnografi membuktikan kemampuan etnografi untuk meng-hasilkan data tentang kehidupan personal maupun domain kehidupan tertentu (Marcen, Gimeno, Gutie-rrez, \& Saenz, 2013), budaya dan kelompok sosial (Madill \& Gough, 2008), serta pengalaman manusia yang terhubung dengan konteks politik, budaya, keluarga, atau intrapersonal (Kearney, 2001). 
Kedua aktivitas yang dibahas, yaitu asesmen psikologi untuk arena klinis (clinical setting) dengan etnografi untuk arena komunitas (community setting), memiliki perbedaan dalam: 1) kerangka yang mendasari pentingnya melihat masalah, yaitu kerangka sudut pandang psikolog (arena klinis) atau kerangka sudut pandang subjek yang mengalami situasi tertentu (arena komunitas); 2) teknik pengukuran yang digunakan, yaitu menempatkan individu dalam posisi pasif (arena klinis) atau aktif (arena komunitas); dan 3) pilihan akan fokus penyelidikan, yaitu membatasi hanya pada keluhan pasien (arena klinis) atau memperluas perhatian pada konteks (arena komunitas), atau dengan kata lain ibaratnya perbandingan keduanya adalah antara berfokus pada pohon (arena klinis) atau hutan (arena komunitas). Dengan perbedaan-perbedaan tersebut, khususnya mencermati perbedaan yang ketiga, maka pembahasan mengenai asesmen psikologi individual dengan psikodiagnostikanya, atau asesmen psikologi komunitas dengan etnografinya, bukan membahas soal mana yang lebih baik atau buruk, melainkan terkait kecocokan dan kemanjurannya. Ketika seorang psikolog menghadapi arena seperti halaman rumah pribadi yang terdiri dari hanya beberapa pohon, maka pekerjaan profesional sebagaimana yang dilakukan para psikolog klinis lebih tepat. Namun, ketika psikolog berhadapan dengan ruang kerja seluas hutan dengan ribuan pohon, maka pendekatan profesional yang dijalankan selama ini oleh psikolog komunitas lebih realistis. Lebih lanjut, etnografi menjadi pilihan teknik yang tepat bagi arena kerja komunitas, mengingat kemampuannya dalam mengungkap konteks yang sejalan dengan prinsip utama dari psikologi komunitas yaitu context-oriented, community-engaged, dan values-driven research and action (Hartmann, St. Arnault, \& Gone, 2018).

Oleh karenanya, atas dasar perbedaan karakteristik ruang kerja dan kesamaan dalam proses penyelidikan di area psikologis, konteks sosial, serta struktural yang terkait dengannya, maka psikolog yang bekerja di arena komunitas perlu mengidentifikasi alat kerja yang sesuai baginya, khususnya untuk tujuan perubahan sosial yang berbasis atau berorientasi pada ranah psikologis individu di komunitas tempat psikolog tersebut bekerja. Dalam kerangka kerja etnografi sebagai dasar perubahan sosial yang berorientasi pada kebutuhan psikologis, maka etnografi sebagai alat kerja psikolog komunitas untuk penjaringan data, dikonseptualisasi sebagai psikoetnografi, yaitu metode etnografi yang berfokus pada fenomena psikis dari orang yang mengalaminya. yaitu the study and impact of culture, tradition and social practices on psyche for the unity of humankind (Belsiyal, 2016) meskipun memiliki kesamaan obyek studi dengan psikoetnografi, namun berbeda dalam dua hal yaitu 1) tidak menekankan pada perspektif orang yang mengalaminya, dan 2) merupakan agregat cabang ilmu, bukan metode penemuan pengetahuan. Psikoetnografi secara terminol ogi lebih dekat dengan autoetnografi yang memusatkan perhatian pada pengalaman individual etnografer dalam studi budaya
(Gergen, 2014), etnografi visual (Kharel, 2015) yang bekerja dengan data visual seperti gambar dan foto, dan digital ethnography (Pink, dkk., 2016), (Kaur-Gill \& Dutta, 2017) atau disebut oleh Hallett \& Barber (2014) sebagai cyber-ethnography. Analog dengan konseptualisasi asesmen psikologi arena klinis sebagai pretreatment evaluation (Meyer, dkk., 2001) karena posisinya sebagai dasar menentukan terapi guna perubahan individual, maka sebagai dasar menentukan bentuk intervensi untuk tujuan perubahan sosial, etnografi juga layak untuk disebut sebagai presocialintervention.

Hasil asesmen psikologi akan menjadi dasar untuk menentukan kebutuhan perubahan pada subjek atau klien dan merancang cara yang tepat untuk memfasilitasi perubahan tersebut (intervensi). Dalam psikologi tradisional, di tahap asesmen psikolog berusaha memahami persoalan personal klien yang bersumber dari pengalaman pribadinya dan membuatnya berada dalam situasi atau permasalahannya saat ini. Analog dengan proses tersebut, dalam arena komunitas, psikoetnografi digunakan untuk memahami persoalan kolektif sekelompok subjek di satu komunitas. Persoalan kolektif tersebut bisa terjadi karena anggota-anggota komunitas mengalami keterpaparan pada stimulus eksternal yang sama, atau melakukan tingkah laku dengan predisposisi yang sama, selama periode waktu yang sama.

\section{Evaluasi penggunaan etnografi sebagai asesmen komunitas: Contoh dari riset tindakan (action research)}

Kami mengevaluasi penggunaan etnografi dalam riset tindakan yang kami lakukan. Riset ini juga kami gunakan sebagai contoh mengenai seperti apa riset psikoetnografi itu. Sehingga, tujuan dari riset ini adalah untuk mengeksplorasi potensi psikoetnografi sebagai alat kerja psikolog di komunitas ketika melakukan asesmen psikologi. Argumen yang dikedepankan disini adalah bahwa psikoetnografi memungkinkan psikolog untuk mendapatkan: 1) pemetaan psikologis yang jelas dan kontekstual dari anggotaanggota komunitas yang berbagi ruang hidup dan pengalaman kolektif yang sama; 2) faktor-faktor intrapersonal, interpersonal, kultural, dan struktural yang menghubungkan pengalaman tersebut; dan 3) cara bagaimana setiap elemen tersebut saling berhubungan membentuk berbagai sirkuit perjalanan sumber daya komunitas dalam konteks ruang dan kontinum waktu hingga di keadaannya saat ini.

Urgensi penelitian tentang penerapan psikoetnografi sebagai pendekatan asesmen di ranah psikologi komunitas diaktivasi oleh perkembangan dinamika lingkungan eksternal makro saat ini yang dikenal sebagai "VUCA world" yang dicirikan oleh volatility (kecepatan perubahan), uncertainty (aspek ketidakmenentuan), complexity (keberagaman), dan ambiguity (ketidakjelasan) (Budiharto, Himam, Riyono, \& Fahmi, 2019), dan berdampak pada lingkup 
mikro di level komunitas dalam berbagai ranah antara lain cara berkomunikasi, proses ekonomi, model dan media pendidikan, dan budaya. Kerangka kerja psikologis individu ketika berhadapan dengan stimulus lingkungan eksternalnya adalah berespon dengan instrumen kognitif, emosional, motivasional, dan perilaku, yang memungkinkannya untuk dapat bertahan dalam konteks perubahan yang terjadi. Oleh karena lingkungan "VUCA" memiliki karakteristik kecepatan, ketidakmenentuan, dan ketidakjelasan, maka banyak kelompok masyarakat yang menghadapinya dengan ketidaksiapan dan berdampak pada munculnya masalah-masalah "person in context" dengan habitat natural yang menjadi konteks dewasa ini tidak hanya habitat fisik tempat seseorang tinggal dan beraktivitas, melainkan meliputi pula habitat daring (online habitant)-nya (Hallett \& Barber, 2014). Internet addiction, mobile phone dependency, cyber crime, parasocial relationship, adalah beberapa di antaranya, disamping perilaku kolektif lain yang bersifat tradisional namun diperkuat oleh dampak tak langsung dari dunia "VUCA" seperti online social movement (Ismail, Munsi, \& Hans, 2019) dan digital discrimination (Weidmann, Baleato, Hunziker, Glatz, \& Dimitropoulos, 2016). Munculnya problem psikologis dan perilaku di level kolektif (kelompok, organisasi, komunitas), yang terhubung dengan dunia "VUCA" memunculkan variasi masalah yang beragam dan sangat kontekstual, menuntut pendekatan asesmen yang memungkinkan untuk dilaksanakan di ruang natural tempat individu berada, efektif dalam waktu dan biaya, serta interpretasi yang lebih "in context" dibandingkan universal norm atau manualbased classification. Kami menawarkan pengaplikasian dari psikoetnografi sebagai instrumen asesmen psikologi yang penting dan tepat dalam menjawab kebutuhan tersebut. Argumen utama kami adalah psikoetnografi dapat menjadi suatu metode dan teknik pengumpulan data yang cocok dan ampuh untuk asesmen psikologi komunitas.

\section{Metode Penelitian}

\section{Peneliti Lapangan}

Penelitian lapangan melibatkan lima orang subjek peserta mata kuliah Etnografi di program studi psikologi jenjang pasca sarjana (S2) di Fakultas Psikologi Universitas Padjadjaran (Unpad). Semua subjek mengaplikasikan metode etnografi sebagai proyek mayor mata kuliah, dengan berfokus pada psikoetnografi sekelompok subjek di suatu komunitas yang menjadi sasaran asesmen. Kelimanya merupakan sarjana psikologi yang sudah memiliki kompetensi riset dasar psikologi yaitu teknik observasi dan wawancara psikologi, baik individual maupun kelompok. Di program pendidikan mereka saat ini, mereka telah mendapatkan pembelajaran tentang dasar-dasar asesmen psikologis dan interpretasi diagnostik yang merupakan kompetensi generik pada rumpun keprofesian psikologi dan menjadi prasyarat bagi keikutsertaan mereka di mata kuliah etnografi. Kerja lapangan ini merupakan program di semester ke-tiga mereka. Masing-masing mahasiswa sudah pernah melakukan asesmen psikologi maupun riset menggunakan observasi dan wawancara, dan belum pernah menggunakan metode etnografi maupun terlibat dalam penelitian etnografi sebelum proyek ini.

\section{Desain}

Model penelitian tindakan (action research) dipilih, dengan penekanan pada analisis dokumen yang dihasilkan dari kegiatan pembelajaran yang bertempat di kampus Universitas Padjadjaran dan tiga arena komunitas. Riset ini didasarkan pada kegiatan pembelajaran yang bertujuan untuk memperkenalkan dan melatih penggunaan metode etnografi dalam asesmen psikologi di arena komunitas. Kurikulum pendidikan profesi psikologi di arena komunitas mewajibkan mahasiswa untuk mencapai kompetensi asesmen psikologi individual pada sekelompok orang yang terhubung satu sama lain dalam ruang kolektif, yang mengalami keterpaparan serupa pada fitur lansekap, kebijakan struktural, perkembangan teknologi khususnya teknologi komunikasi, dan lingkungan sosial yang sama.

Dengan demikian, desain penelitian ini menyaratkan dilangsungkan kegiatan pembelajaran selama enam bulan (satu semester) yang meliputi beberapa tahapan kegiatan (lihat bagian prosedur penelitian) sebagai bagian dari proses pembelajaran mata kuliah etnografi yang kemudian menghasilkan dokumen-dokumen yang menjadi sumber atau bahan utama riset ini. Adapun observasi dan percakapan yang muncul selama kegiatan pembimbingan maupun visitasi lapangan tidak disertakan sebagai sumber data, semata-mata karena sasaran utama dari riset ini adalah untuk memperlihatkan cakupan isi atau konten psikologi yang dapat diperoleh melalui pengaplikasian metode psikoetnografi di komunitas.

\section{Prosedur}

Penelitian meliputi tiga tahap, yaitu tahap 1) pembelajaran dengan bahan ajar yaitu pengetahuan tentang metode etnografi, 2) pelatihan teknik pengumpulan data etnografi, dan 3) pelatihan menganal isis data etnografi dan penyusunan laporan. Pertama, pembelajaran tentang metode etnografi berbentuk perkuliahan tatap muka di dalam kelas, berlokasi di kampus. Capaian pembelajaran pada tahap ini adalah mahasiswa menguasai pengetahuan tentang metode etnografi dan bisa menjelaskan perbedaannya dengan metode riset kualitatif lainnya. Mahasiswa partisipan juga mempelajari teknikteknik yang lazim digunakan dal am pengambilan data etnografi, serta mempelajari minimal satu laporan etnografi dari seorang etnografer, agar mahasiswa mengalami menghayati fenomena dari sekelompok subjek yang diteliti melalui pandangan seorang etnografer. Dari kuota perkuliahan yaitu 16 x 2 jam pertemuan untuk mata kuliah etnografi, pembelajaran sesi pengetahuan mendapatkan alokasi empat 
pertemuan, dengan rincian kuliah tatap muka dan tugas terstruktur masing-masing 400 menit (4 pertemuan x 2 sks x 50 menit).

Kedua, melatih ketrampilan teknik pengumpulan data etnografi di komunitas yang dipilih, yaitu kampung miskin perkotaan (KMP) yang berlokasi di DKI Jakarta, komunitas desa hutan (KDH) di kabupaten Garut, dan komunitas desa broadband (KDB) di kabupaten Tasikmalaya. Di KMP satu mahasiswa, sedangkan di kedua arena yang lain masing-masing dua mahasiswa. Ketiga tempat dipilih sebagai respon atas kondisi nyata masyarakat yang berada dalam situasi rencana perubahan, atau tekanan untuk melakukan perubahan, atau resisten terhadap rencana perubahan, dan membutuhkan pendampingan untuk memfasilitasi proses tersebut. Melakukan riset di lebih dari satu arena memungkinkan diidentifikasinya kemampuan etnografi ketika diterapkan di arena yang berbeda-beda.

KMP adalah komunitas masyarakat prasejahtera yang terkena dampak penggusuran akibat kebijakan tata ruang yang dilakukan oleh pemerintah propinsi DKI Jakarta tahun 2015. Saat ini mereka tinggal di hunian sementara (huntara) yang dibangun tahun 2018 ketika perkampungan asli mereka yang sudah ditempati selama kurang lebih tiga generasi, dirobohkan oleh pemerintah propinsi DKI Jakarta pada saat itu dan penduduknya digusur. Dari jumlah semula ratusan $\mathrm{KK}$, saat ini tersisa $33 \mathrm{KK}$ yang tinggal di huntara tersebut. Huntara tersebut dibangun oleh pemerintah propinsi di masa kepemimpinan gubernur yang baru, di satu lahan tidak jauh dari lokasi kampung mereka semula. Sebagian besar penghuni kampung yang tergusur, memilih untuk pulang ke kampung halaman di luar Jakarta atau pindah ke rumah susun yang disediakan oleh pemerintah sebagai pengganti rumah yang digusur. Sebagiannya lagi bertahan di tanah bekas penggusuran. Kondisi huntara untuk setiap unit berukuran $3 \times 6 \mathrm{~m}$, terbagi menjadi dua ruangan masing-masing berukuran $3 \times 3 m$ dan dihuni oleh 4-5 orang. Dapur dan kamar mandi tersedia dalam bentuk dapur dan kamar mandi bersama untuk seluruh penghuni huntara.

Saat ini masyarakat sedang berupaya untuk memenuhi kebutuhan bersama yaitu mendapatkan kembali hak atas tanah dan hunian tetap mereka. Mereka ingin mengembalikan community well-being pasca penggusuran, namun belum tergugah untuk melakukan upaya bersama. Mereka diberikan syarat untuk mampu mengelola komunitas dan koperasi sebelum dinyatakan layak mendapat sertifikat tanah komunal. Fenomena di lapangan adalah minimnya pengetahuan anggota masyarakat mengenai mekanisme pengelolaan koperasi dan adanya sebagian anggota masyarakat yang enggan untuk berpartisipasi dalam kegiatan yang bertujuan untuk meramaikan iklimsosial kampung.

KDH adalah suatu desa yang berlokasi di lereng gunung dan dikelilingi oleh hutan. Pekerjaan sebagian besar penduduknya saat ini adalah petani kopi, yang dahulunya adalah petani sayur. Di awal tahun 2000-an terjadi bencana longsor di daerah tersebut, yang disadari salah satunya adalah karena ketiadaan pohon besar akibat ditebangnya pohonpohon ketika para petani membuka lahan untuk kebun sayur. Kesadaran warga akan perlunya penghutanan kembali pasca bencana, difasilitasi oleh suatu paguyuban warga setempat yang mencintai lingkungan, menghasilkan kesediaan para petani untuk berpindah dari petani sayur ke petani kopi. Kopi dipilih karena sifat tanamannya yang membutuhkan pohon peneduh untuk tumbuh kembangnya, sehingga menanam kopi akan harus menanam dan merawat pohon besar sebagai peneduhnya. Di tengah derasnya kebutuhan akan kopi dewasa ini, para petani KDH sudah memetik hasil dari kopinya dan sudah mendapatkan manfaat dari penjagaan hutan yang mereka rintis selama ini. Saat ini, para petani sampai pada kesadaran bahwa sebagian besar petani kopi berusia antara 40-60 tahun, sementara sebagian besar anakanak mereka tidak menunjukkan minat untuk memilih pekerjaan sebagai petani kopi melanjutkan apa yang sudah dirintis oleh ayah atau kakeknya. Kesadaran tersebut belum sampai pada solusi, mengingat saat ini, generasi di bawah usia 40 tahun di desa tersebut sebagian besar bekerja sebagai buruh atau pegawai di luar desanya.

KDB adalah desa terpencil yang mendapatkan akses internet gratis melalui program Kementerian Komunikasi dan Informasi sejak tahun 2017. Biasanya desa dipilih karena adanya beberapa indikator kesejahteraan yang lebih rendah dari standar nasional atau propinsi, antara lain indeks kesehatan dan pendidikan. KDB berlokasi jauh dari ibukota kecamatan, sehingga relatif sulit menjangkau layanan kesehatan puskesmas, demikian pula sebaliknya. Sebagai desa di wilayah kabupaten dengan angka kejadian stunting tinggi dan indeks kesehatan berada di bawah rata-rata nasional dan propinsi, KDB mendapat perhatian khusus dari pemerintah, salah satunya menjadikan KDB mendapatkan peningkatan akses terhadap informasi kesehatan maupun layanan pemerintah lainnya. Institusi pendidikan hanya ada hingga jenjang SMP, dan ada tambahan satu SMK yang didirikan oleh warga setempat guna merespon kebutuhan tenaga terampil bidang IT pasca dipilihnya KDB sebagai desa broadband. Kondisi saat ini, muncul kebiasaan baru pada remaja KDB yang terkait dengan terhubungnya mereka dengan dunia maya secara umum dan khususnya media sosial, yaitu tingginya intensitas penggunaan gawai khususnya di tempat kerja atau sekolah dimana koneksi internet tersedia secara gratis.

Sesi praktek atau kegiatan lapangan oleh mahasiswa di ketiga arena komunitas tersebut pada mata kuliah etnografi, diintegrasikan dengan sesi praktek pada mata kuliah praktek kerja profesi peminatan psikologi komunitas. Mata kuliah praktek kerja tersebut berbobot empat sks, sehingga total jumlah sks mahasiswa di lapangan adalah enam sks, yang dilaksanakan dalam rata-rata empat hari setiap minggu selama dua belas minggu. Bobot kegiatan lapangan pada mata kuliah etnografi ini disetarakan dengan delapan pertemuan mata kuliah. Secara 
periodik mahasiswa mengirimkan catatan etnografinya via surat elektronik kepada dosen pengampu, dan hingga akhir kegiatan lapangan setiap mahasiswa kurang lebih telah menghasilkan 3-4 catatan etnografi, presentasi lisan pada saat sesi monitoring dan evaluasi di tengah semester, dan logbook yang mendokumentasikan seluruh kegiatannya di lapangan.

\section{Tabel 1.}

Ilustrasi tema intrapsikis pada ketiga arena komunitas

\begin{tabular}{|c|c|c|c|}
\hline $\begin{array}{c}\text { Ranah } \\
\text { Intrapsikis }\end{array}$ & KMP & $\mathrm{KDH}$ & KDB \\
\hline \multirow[t]{2}{*}{ Kognitif } & $\begin{array}{l}\text { Sebagian warga } \\
\text { mengekspresikan } \\
\text { penerimaan pasif atas } \\
\text { penempatan mereka di } \\
\text { huntara. }\end{array}$ & $\begin{array}{l}\text { Sebagian petani menyadari } \\
\text { pentingnya regenerasi petani } \\
\text { kopi untuk keberlangsungan } \\
\text { penjagaan hutan. }\end{array}$ & $\begin{array}{l}\text { Kehadiran akses daring } \\
\text { tidak meningkatkan } \\
\text { pengetahuan remaja } \\
\text { putri akan hubungan } \\
\text { antara asupan makanan- } \\
\text { anemia-resiko pada } \\
\text { kehamilan. }\end{array}$ \\
\hline & $\begin{array}{l}\text { Sebagian warga } \\
\text { mengekspresikan } \\
\text { penerimaan aktif atas peng- } \\
\text { huntara-an mereka, dengan } \\
\text { kesediaan mencoba setiap } \\
\text { kesempatan untuk mengubah } \\
\text { status hunian. }\end{array}$ & & $\begin{array}{l}\text { Ketidaktahuan akan } \\
\text { pengertian stunting dan } \\
\text { cara penanganannya } \\
\text { pada anggota keluarga } \\
\text { yang menjadi care giver } \\
\text { bayi dan anak. }\end{array}$ \\
\hline Afektif & $\begin{array}{l}\text { Sebagian warga masih } \\
\text { merasa kecewa dan marah, } \\
\text { yang terhubung dengan } \\
\text { pemerintah propinsi dan unit } \\
\text { kerja yang relevan di } \\
\text { bawahnya. }\end{array}$ & $\begin{array}{l}\text { Merasakan kepuasan dan } \\
\text { kebahagiaan atas pencapaian } \\
\text { materi sebagai petani kopi } \\
\text { dan keberhasilan menjaga } \\
\text { hutan (menjamin } \\
\text { ketersediaan air sepanjang } \\
\text { tahun dan ketiadaan bencana } \\
\text { alam selama ini). }\end{array}$ & $\begin{array}{l}\text { Rasa malu jika belum } \\
\text { menikah selewat masa } \\
\text { remaja. } \\
\text { Merasa tertarik untuk } \\
\text { mencoba makanan cepat } \\
\text { saji yang dilihat di media } \\
\text { sosial dan merasa puas } \\
\text { ketika mendapatkannya. }\end{array}$ \\
\hline \multirow[t]{2}{*}{ Motivasi } & $\begin{array}{l}\text { Sebagian mengerahkan usaha } \\
\text { untuk merespon setiap } \\
\text { kesempatan untuk mengubah } \\
\text { status pemukiman menjadi } \\
\text { hunian tetap dan permanen } \\
\text { (bukan huntara) di lokasi } \\
\text { tersebut, bukan pindah ke } \\
\text { lokasi lain. }\end{array}$ & $\begin{array}{l}\text { Menunjukkan kesediaan } \\
\text { mempelajari perkopian untuk } \\
\text { meningkatkan penghasilan } \\
\text { melalui peningkatan kualitas } \\
\text { kopi dan hasil panen. }\end{array}$ & $\begin{array}{l}\text { Orang tua akan segera } \\
\text { menikahkan anak } \\
\text { perempuannya selepas } \\
\text { remaja. } \\
\text { Akses tanpa batas lewat } \\
\text { daring tidak } \\
\text { dimanfaatkan oleh } \\
\text { remaja putri untuk lebih } \\
\text { berdaya, seperti } \\
\text { menuntut ilmu atau } \\
\text { bekerja }\end{array}$ \\
\hline & $\begin{array}{l}\text { Sebagian memfokuskan } \\
\text { tenaganya untuk bisa } \\
\text { bertahan dengan kondisi } \\
\text { hunian saat ini, dengan alasan } \\
\text { kelelahan psikis akibat } \\
\text { ketidakberhasilan dalam } \\
\text { berbagai usaha yang sudah } \\
\text { pernah dilakukan bersama } \\
\text { selama ini. }\end{array}$ & & $\begin{array}{l}\text { Remaja putri lebih } \\
\text { berfokus pada perilaku } \\
\text { menjaga penampilan diri } \\
\text { untuk persiapan } \\
\text { mendapatkan pasangan } \\
\text { hidup daripada menjaga } \\
\text { kesehatan (pola makan) } \\
\text { maupun menempuh } \\
\text { pendidikan dengan } \\
\text { berorientasi pada } \\
\text { prestasi (pemanfaatan } \\
\text { waktu luang). }\end{array}$ \\
\hline
\end{tabular}

Ketiga, melatih keterampilan menganalisis data di ruang kelas di kampus, dengan bobot empat pertemuan. Mahasiswa partisipan menyusun laporan etnografi sebagai tugas individual, bertempat di kampus dan disupervisi oleh dosen pengampu mata kuliah. Laporan disusun dalam format makalah ilmiah yang merupakan tugas akhir dari mata kuliah etnografi. 


\section{Teknik Analisis Data}

Pasca berakhirnya mata kuliah etnografi, terkumpul data lapangan dari kerja mahasiswa yaitu dua puluh dokumen catatan etnografi dari kelima mahasiswa, lima catatan harian (logbook), dan lima makalah ilmiah. Jenis datanya adalah verbatim dan foto. Analisis tematik diaplikasikan untuk mengategorisasi data ke dalam tema-tema, dengan penentuan tema berbasis pada dimensi psikologis dan komunitas, menggunakan perspektif dan konseptualisasi psikologi komunitas, untuk menunjukkan argumen bahwa psikoetnografi dapat menjadi suatu metode pengumpulan data dalam asesmen psikologi di komunitas.

\section{Hasil Penelitian}

Sebagai sebuah tahap pra-intervensi psikologi, asesmen psikologi perlu menghasilkan data berupa data psikologis individu atau sekelompok individu. Pengolahan data etnografi menggunakan analisis tematik untuk tujuan asesmen kelompok di arena komunitas pun perlu menghasilkan data pada ranah psikologis para subjek di arena tersebut Cuplikan kategorisasi tema psikologis yang ditemukan pada ketiga arena komunitas yaitu KMP, KDH, dan KDB, disajikan pada tabel 1.

Selain data pada ranah intrapsikis, diidentifikasi pula data psikis yang terhubung dengan lingkungan eksternal. Contoh datanya disajikan pada tabel 2. Berdasarkan kategorisasi tema intrapsikis, psikososial, dan ekologis, disusun analisis dinamika psikologis ketiga komunitas, kemudian disusun prediksi kebutuhan perubahan atau kebutuhan intervensi psikologisnya. Dinamika psikologis komunitas disajikan secara berurutan pada Data 1-3 yang disajikan secara berurutan pada gambar 1 , gambar 2 dan gambar 3 pada lampiran.

Dalam gambar 1, kedua alternatif pilihan tersebut menuntut perubahan perilaku yang berbeda pada anggota komunitasnya, dan sebagai psikolog komunitas, hasil tersebut mengisyaratkan kebutuhan intervensi psikologis yang juga berbeda, antara 1) ketika komunitas mampu menyepakati pilihan mereka; atau 2) komunitas tidak mampu menyepakati pilihan mereka.

Fakta yang disajikan pada gambar 2, mengisyaratkan akan adanya kebutuhan KDH untuk suksesi dalam ranah penjagaan hutan melalui pertanian kopi, yang prioritasnya adalah 1) menjadikan pekerjaan petani kopi memiliki nilai atau valensi positif bagi anggota KDH yang lebih muda; 2) menyadari hubungan antara pekerjaan tersebut dengan penjagaan keselamatan $\mathrm{KDH}$ dari bencana alam; dan 3) memun-culkan kesediaan atau motivasi anggota KDH muda untuk memilih profesi tersebut sebagai pekerjaannya.
Psikolog komunitas, berdasarkan fakta pada gambar 3, dapat melihat adanya kebutuhan komunitas untuk: 1) reorganisasi dalam pengelolaan sumber daya khususnya koneksi internet; 2) menyepakati ragam pemanfaataan sumber daya daring yang diperbolehkan oleh komunitas; 3) suksesi figur otoritas yang dapat mengambil keputusan (menjadi pemimpin) untuk komunitas.

\section{Diskusi}

Mencermati penelitian yang telah kami paparkan, etnografi dapat menghasilkan data psikologis sekelompok orang di suatu komunitas. Kedalaman data psikologis yang diperoleh melalui kesempatan melakukan observasi psikologis dalam percakapan informal, wawancara individual maupun kelompok, dan teknik etnografi lainnya, memungkinkan adanya etnografi yang berfokus pada psikologi atau layak disebut sebagai psikoetnografi.

Mengintegrasikan psikologi dengan etnografi bukan hal baru, mengingat telah dikenal lebih dulu terminologi ethnographic psychoanalysis (Cargill, 2006) dan ethnopsychology (Hollan, 2016). Istilah psikoetnografi mulai banyak digunakan di tahun 1950-an oleh para peneliti yang memakai pendekatan etnografi untuk memahami kondisi psikologis atau kepribadian suatu masyarakat budaya tertentu, misalnya Mead dan Mcgregor saat menjelaskan perkembangan anak dan budaya (Whiting, 1953) atau Galdwin dan Sarason saat menjelaskan kepribadian dari budaya Trukese (Schneider, 1955). Psikoetnografi juga digunakan dengan pengertian yang berbeda, yaitu oleh Margaret Mead dan Rhoda Metraux (Wallace, 1954, hal. 1142) yang menyebut psikoetnografi sebagai "study of culture at a distance", sebuah metode untuk memahami budaya melalui perilaku individu. Di masa itu terjadi perkembangan di bidang antropologi mengenai kajian kebudayaan dan kepribadian yang diinisiasi oleh figur-figur terkenal seperti Sapir, Mead, Benedict, Hallowell, Kardiner, dan Linton. Neologisme psikoetnografi ini mengisyaratkan adanya kerja interdisiplin antara dua bidang studi namun juga terkait penerapan metode etnografi untuk menjelaskan aspek psikologis yang pada perkembangannya berusaha dibedakan dari folk psychology yang muncul di Belanda atau istilah etnopsikologi yang lebih diterima secara umum (Barre, 1955).

Di Indonesia, istilah psikoetnografi digunakan oleh Nanum Sofia dan Johana E. Prawitasari (2016) dalam menjelaskan metode etnografi yang dipakai untuk mengeksplorasi berbagai aspek psikologi. Penelitian ini menggunakan pengertian psikoetnografi yang sama dengan yang diberikan 
Tabel 2.

Ilustrasi tema psikososial dan ekologispada ketiga arena komunitas. Teori ekologismerujukpada Brofenbrenner (Moritsugu, Vera, Wong, \& Duffy, 2016)

\begin{tabular}{|c|c|c|c|}
\hline $\begin{array}{c}\text { Ranah } \\
\text { Psikososial }\end{array}$ & KMP & $\mathrm{KDH}$ & KDB \\
\hline \multirow[t]{2}{*}{ Interpersonal } & $\begin{array}{l}\text { Mengalami konflik internal } \\
\text { berkelanjutan dalam } \\
\text { pemanfaatan dapur bersama } \\
\text { karena faktor "menawari } \\
\text { tetangga tidak ingin", tapi } \\
\text { "tidak menawari rasanya } \\
\text { tidak pantas". }\end{array}$ & $\begin{array}{l}\text { Memiliki harapan agar ada } \\
\text { penerus di dalam keluarga } \\
\text { untuk menjaga hutan dan } \\
\text { bertani kopi. }\end{array}$ & $\begin{array}{l}\text { Keharusan remaja putri } \\
\text { untuk patuh pada } \\
\text { ayahnya dalam urusan } \\
\text { menikah. }\end{array}$ \\
\hline & & $\begin{array}{l}\text { Sebagian petani mulai } \\
\text { mengenalkan anaknya pada } \\
\text { perkopian, meskipun saat ini } \\
\text { terdapat ragam respon anak } \\
\text { antara menolak dan } \\
\text { menerima. }\end{array}$ & $\begin{array}{l}\text { Pengetahuan ibu tentang } \\
\text { rumah tangga tidak } \\
\text { disosialisasikan pada } \\
\text { remaja putri dengan } \\
\text { anggapan akan tahu } \\
\text { dengan sendirinya pada } \\
\text { saat menikah. }\end{array}$ \\
\hline \multirow[t]{2}{*}{$\begin{array}{l}\text { Intra kelompok \& } \\
\text { mikrosistem }\end{array}$} & $\begin{array}{l}\text { Terhadap sesama warga se- } \\
\text { huntara ada perasaan saling } \\
\text { membutuhkan. Beberapa } \\
\text { warga mengharapkan saling } \\
\text { mendukung, yang disertai } \\
\text { perasaan kecewa ketika } \\
\text { harapan akan dukungan tidak } \\
\text { terpenuhi. }\end{array}$ & $\begin{array}{l}\text { Petani yang memasuki lansia } \\
\text { anaknya tidak menjadi petani } \\
\text { kopi mengalihkan lahan } \\
\text { kopinya untuk dikelola petani } \\
\text { sepaguyuban dengan } \\
\text { berharap lahannya tetap } \\
\text { difungsikan untuk kopi dan } \\
\text { menjaga hutan. }\end{array}$ & $\begin{array}{l}\text { Orang tua dan remaja } \\
\text { putri mengalami tekanan } \\
\text { sosial dari komunitas } \\
\text { untuk segera menikah } \\
\text { ketika memasuki usia } \\
\text { remaja. }\end{array}$ \\
\hline & & & $\begin{array}{l}\text { Tidak ada media yang } \\
\text { optimal untuk } \\
\text { komunikasi pengasuhan } \\
\text { orang tua-anak di rumah. }\end{array}$ \\
\hline \multirow[t]{2}{*}{$\begin{array}{l}\text { Antar kelompok \& } \\
\text { mesosistem }\end{array}$} & $\begin{array}{l}\text { Ada orang-orang yang aktif } \\
\text { mengorganisasikan warga } \\
\text { untuk merencanakan } \\
\text { tindakan kolektif kepada } \\
\text { pemerintah propinsi. }\end{array}$ & $\begin{array}{l}\text { Para petani kopi meminta } \\
\text { bantuan paguyuban untuk } \\
\text { membina anak-anak mereka } \\
\text { agar mau menjadi petani kopi. }\end{array}$ & $\begin{array}{l}\text { Akses daring } \\
\text { memunculkan kebutuhan } \\
\text { tersier baru (fashion, } \\
\text { hiburan daring) pada } \\
\text { remaja dan perilaku baru } \\
\text { yang relevan. }\end{array}$ \\
\hline & $\begin{array}{l}\text { Sebagian bekerja di sektor } \\
\text { informal meneruskan } \\
\text { pekerjaan orang tua dan } \\
\text { kakeknya di lokasi sekitar } \\
\text { kampung, merasa punya } \\
\text { ikatan dengan lokasi dan } \\
\text { pekerjaan tersebut sehingga } \\
\text { enggan memilih solusi pindah } \\
\text { ke rusun karena jauh dari } \\
\text { lokasi saat ini. }\end{array}$ & $\begin{array}{l}\text { Merespon kebutuhan petani, } \\
\text { paguyuban } \\
\text { menyelenggarakan kursus } \\
\text { gratis perkopian untuk anak } \\
\text { (kegiatan "kopi kids") di luar } \\
\text { waktu sekolah. }\end{array}$ & \\
\hline $\begin{array}{l}\text { Mesosistem dan } \\
\text { makrosistem }\end{array}$ & $\begin{array}{l}\text { Kesadaran bersama untuk } \\
\text { menyuarakan situasi tidak } \\
\text { manusiawi yang mereka } \\
\text { terima kepada publik, agar } \\
\text { ada tekanan pada pemerintah } \\
\text { untuk memperbaiki keadaan } \\
\text { hunian mereka. Namun } \\
\text { alternatif pindah yang } \\
\text { ditawarkan oleh pemerintah } \\
\text { tidak bisa dipilih karena tidak } \\
\text { realistis dalam hubungannya } \\
\text { dengan pekerjaan dan lokasi } \\
\text { kerja mereka saat ini. }\end{array}$ & $\begin{array}{l}\text { Paguyuban melibatkan } \\
\text { konsultan untuk menyusun } \\
\text { kurikulum sekolah kopi yaitu } \\
\text { sekolah yang akan } \\
\text { mengajarkan perkopian dari } \\
\text { hulu ke hilir. }\end{array}$ & $\begin{array}{l}\text { Pasca pilpres } 2019 . \\
\text { penyebaran HOAX } \\
\text { diantara warga KDB yang } \\
\text { tinggal di KDB ataupun di } \\
\text { luar KDB, memperuncing } \\
\text { perbedaan ideologi } \\
\text { politik antar warga. }\end{array}$ \\
\hline
\end{tabular}


Gambar 1.

Data dinamika psikologis Komunitas Miskin Perkotaan (KMP).

KMP saat ini terdiri dari sekelompok kecil anggota komunitas yang aktif (kelompok aktivis) mengupayakan legalisasi atas lahan tempat mereka tinggal saat ini, kelompok kecil lain yang mendukung kelompok kecil pertama secara psikologis tapi tidak aktif dalam dukungan instrumental atau keterlibatan perilaku, serta kelompok lebih besar yang bersikap apatis dan menunjukkan ketiadaan min at untuk bergabung maupun mendukung secara psikologis. Perbedaan sikap dan tindakan pada ketiga kelompok tersebut menempatkan komun itas tersebut sebagai locality based community namun tidak optimal sebagai relational community (Kloos, Hill, Thomas, Wandersman, Elias, \& Dalton, 2012), dengan dicirikan oleh perasaan lelah kelompok aktivis yang merasa melakukan banyak hal untuk komunitas mereka, namun dengan ketiadaan dukungan anggota komunitas lain sesuai taraf yang mereka harapkan. Kloos dkk. menjelaskannya sebagai situasi ketidakseimbangan alokasi sumber daya personal terhadap komunitas, antara anggota komunitas yang satu dengan anggota komunitas yang lain. Melalui perspektif ekologis pada ranah cycling of resources (Kloos, Hill, Thomas, Wandersman, Elias, \& Dalton, 2012), dapat dilihat bahwa situasi tersebut berpeluang menyebabkan hilangnya sumber daya yang ada pada kelompok aktivis tersebut akibat tidak terjadinya arus transformasi sumber daya yang seimbang di seluruh anggota komunitas. Jika hal tersebut terjadi, maka hilang pula kesempatan komunitas ini untuk mengubah status hunian mereka, mengingat saat ini sumber daya untuk melakukannya hanya ada pada kelompok aktivis.

Dalam situasi demikian, maka menggunakan perspektif ekologis pada ranah adaptasi, pi lihan yang dimiliki komunitas adalah 1) beradaptasi pada sistem hunian yang bersifat komunal melalui perubahan perilaku sosial, dari perilaku sosial yang sesuai untu k hubungan pertetanggaan rumah inidvidual menjadi yang sesuai untuk rumah bersama, dimana a rea memasak, mandi, dan mencuci tidak privat sebagaimana di rumah individual, melainkan merupakan area publik yang harus berbagi kesempatan menggunakannya dengan penghuni lain; 2) beradaptasi dengan berupaya mengubah iklim kampung menjadi konsep bermukim individual seperti layaknya konsep bermukim metrop olis. Masing-masing pilihan membutuhkan proses hingga ke level pemangku kepentingan tingkat propinsi.

\section{Gambar 2.}

Data dinamika psikologis Komunitas Desa Hutan (KDH).

KDH memiliki kesatuan sikap pada anggota komunitasnya, yaitu para petani yang pada umumnya juga kepala keluarga, bahwa regenerasi petani kopi diperlukan tidak hanya untuk mempertahankan usaha keluarga, melainkan untuk menjag a keselamatan wilayah tinggal mereka melalui menjaga alam dari bencana alam. Mereka hanya belum tahu bagaimana cara mewujudkannya. Prioritas mereka adalah meregenerasikannya pada anggota keluarga yang lebih muda, namun pengaruh global terhadap anak-anak dan remaja melalui keterpaparan mereka pada pendidikan dan informasi global, menjadikan sebagian besar anak-anak mereka tidak memiliki orientasi masa depan sebagai petani kopi. Dalam hal kopi, anak-anak dan remaja lebih memberikan penilaian positif pada profesi barista dibandingkan petani kopi. Perspektif ekologis melihatnya sebagai ketiadaan suksesi (Kloos, Hill, Thomas, Wandersman, Elias, \& Dalton, 2012), dimana komunitas tidak memiliki mekanisme yang mandiri untukmempertahankan keberlangsungan sistem di komunitasnya, dalam hal ini adalah sistem peny ediaan sumber daya. Anak dan remaja yang orientasi masa depannya berfokus pada pendidikan tinggi dan menja di pekerja kantor di kota atau yang tidak meminati pendidikan tinggi dan memilih menjadi buruh, tidak akan bisa menjadi penyedia sumber daya alam di KDH.

Para petani kopi di KDH saat ini, adalah mereka yang memilih menjadi petani kopi melalui proses perke mbangan kesadaran, dari kesadaran individual akan perlunya menjaga hutan sebagai pencegah bencana alam, menjadi kesadaran kolektif akan hal yang sama . Merupakan proses komunitas yang tidak mudah dan membutuhkan waktu bertahun -tahun, tapi pengalaman langsung mereka ketika mengalami bencana alam membuat mereka memiliki motivasi untuk tidak mengalaminya kembali. Perbedaan mereka dengan anak-anak dan remaja anggota komunitas adalah, bahwa anak-anak dan remaja tersebut tidak mendapatkan pengalaman langsung terpapar pada bencana. Ketiadaan pengalaman tersebut, disertai dengan ketiadaan kisah yang diteruskan dari orang tua kepada anak tentang bencana ter sebut, atau dari anggota komunitas yang lebih tua kepada anggota komunitas yang lebih muda, membuat kelompok anak-anak dan remaja ini menjadi tidak terhubung dengan pengalaman orang tua atau anggota-anggota komunitas yang lebih tua lainnya, dan tidak terhubung pula dengan konteks psikologis yang memotivasi generasi orang tua tersebut untuk bertanam kopi. Dalam perspe ktif psikologi komunitas, mereka seperti tidak menjadi bagian dari komunitas petani kopi sebagai locality based community (Kloos, Hill, Thomas, Wandersman, Elias, \& Dalton, 2012), dan lebih menjadi bagian dari relational community (Kloos, Hill, Thomas, Wandersman, Elias, \& Dalton, 2012) bersama generasi sebaya mereka.

\section{Gambar 3 .}

Data dinamika psikologis Komunitas Desa Broadband (KDB).

KDB merupakan komunitas yang remaja usia SMP dan SMA-nya memiliki keterkejutan budaya pasca perkenalan mereka dengan dunia maya, yang tidak diketahui oleh anggota KDB pada generasi orang tua mereka, sebagai akibat dari ketidakpahaman orang tu a akan apa yang bisa diakses oleh anak melalui telepon genggamnya. Remaja usia SMP dan SMA beradaptasi dengan "duniabaru" mereka dengan cara mereka sendiri antara lain dalam perubahan pilihan kegiatan waktu luang dan perubahan kebiasaan seperti kebiasaan berpak aian, pilihan makanan, dan pola berbelanja. Tujuan dïntervensinya desa untuk menjadi desa broadband yaitu agar terbuka akses pada sumber pembelajaran dan pengetahuan atau informasi kesehatan, sejauh ini belum terwujud. Ketersediaan akses internet gratis tanpa di sertai penjelasan masif dari otoritas KDB menjadi faktor penyebab remaja menetapkan pilihan dan batasan mereka sendiri. Saat ini, pi lihan tersebut tidak sejalan dengan tujuan diadakannya KDB oleh pemangku kepentingan di level mesosistem yaitu untuk meningkatkan pengetahuan kesehatan dan selanjutnya menerapkannya untuk meningkatkan taraf kesehatan masyarakat, khususnya perihal stunting. Id entifikasi tentang perubahan pada remaja putri yang terhubung dengan keterpaparan mereka padadunia maya, memperlihatkan bahwa perubahan yang terjadi lebih banyak padaranah konsumerisme seperti pola berbelanja serta pilihan pakaian dan makanan.

Bagi KDB, internet merupakan sumber daya baru yang aksesibilitasnya tidak membutuhkan biaya serta tidak membutuhkan orang dewasa atau figur otoritas, baik sebagai pintu akses maupun untuk membimbing penggunaannya. Maka menjadi logis jika arah pemanfaatan sumber dayanya menuju pada tempat yang tidak direncanakan pemangku kepentingan yang relevan. Dalam hal ini, perubahan yang diharapkan adalah terjadinya peningkatan pengetahuan kesehatan dan aplikasinya khususnya untuk mencegah stunting, sedangkan arah perubahannya sama sekali tidakmendekati tujuan tersebut. Perspektif ekologis terhadap perjalanan sumber daya tersebut mengindikasikan lemahnya saling ketergantungan (Kloos, Hill, Thomas, Wandersman, Elias, \& Dalton, 2012) di antara anggota komunitas, dalam hal ini yaitu penyedia koneksi in ternet, penanggung jawab kesehatan komunitas, penanggung jawab pendidikan formal (seko lah), orang tua, dan remaja, yang menyebabkan terjadinya pemanfaatan sumber daya yang tidak produktif dan tidak konstruktif terhadap kebutuhan komunitas. 
oleh Sofia dan Prawitasari terhadap psikoetnografi. Intinya adalah etnografi untuk memfokuskan perhatian atau penyelidikan pada aspek psikologis dari perilaku individu-individu anggota komunitas. Dalam penelitian ini, psikoetnografi menghasilkan data psikologis untuk diinterpretasi hingga memunculkan dinamika psikologis sejumlah orang dalam kelompok atau komunitas, menjadikannya dasar untuk menentukan kebutuhan intervensi psikologis yang kontekstual dan selanjutnya mengidentifikasi alternatif intervensi psikologis yang relevan dan realistis untuk dijalankan.

Pertanyaan yang mungkin muncul terkait kuailtas asesmennya, dapat dijawab dengan menganalogikannya pada interview dan observasi klinis di ruang pemeriksaan psikologi. Ketika profesi psikolog mengklaim bahwa observasi dan wawancara psikologi adalah alat diagnostik yang sah digunakan dalam asesmen psikologi, maka kedua teknik tersebut bisa menjadi alat yang sama ketika digunakan di ruang klinik maupun di ruang natural seperti komunitas. Psikoetnografi sebagai pendekatan yang memayungi aplikasi kedua teknik tersebut dalam asesmen psikologi di komunitas, menempati posisi serupa dengan pendekatan humanistik atau psikoanalisa yang memayungi kedua teknik dalam asesmen kepribadian di klinik, rumah sakit, atau sekolah.

Di era disruptif ketika sumber belajar tidak hanya buku, ketika belajar tidak harus di sekolah, ketika konsultasi kesehatan tidak harus di klinik, ketika berbelanja kebutuhan bisa dilakukan dari rumah, maka jasa layanan psikologi pun perlu adaptif menyesuai potensi dan kesempatan. Perkembangan teknologi informasi memberi kontribusi terhadap keterbukaan berbagai aset yang dapat diakses dan dimanfaatkan bersama, termasuk instrumen pemeriksaan psikologi yang di masa lampau dipelajari hanya oleh mahasiswa psikologi di kampus dengan usaha sedemikian rupa untuk menjaga kerahasiaannya, saat ini tersedia secara terbuka di dunia maya dan bisa diakses untuk dipelajari oleh siapapun. Membendung keterbukaan tersebut bukan sesuatu yang realistis di era ini. Yang bisa dilakukan adalah menyiapkan diri untuk tidak mengandalkan kinerja profesi hanya pada "alat kerja" yang keterandalannya melekat pada kerahasiaannya, sehingga ketika kerahasiaan tidak bisa dipertahankan lagi, maka hilang pula keterandalannya. Psikolog perlu melihat kembali modalitas yang dimiliki psikolog sebagai peneliti kual itatif, dimana instrumen utamanyaadalah peneliti sendiri, melalui perilaku mengobservasi dan mewawancara. Mengandalkan diri pada kemampuan mengobservasi dan mewawancara, menjadi lebih dapat diandalkan di masa ini dibandingkan mengandalkan diri pada alat pemeriksaan psikologi yang soal, kunci jawaban, dan cara interpretasinya sudah bisa diakses secara terbuka oleh siapapun. Riset dan makalah etnografi ini disajikan untuk menjadi alternatif yang bisa dipertimbangkan sebagai alat kerja psikologi untuk riset atau asesmen, pada mereka yang sampai pada kesadaran era disruptif.

\section{Kesimpulan}

Bekerja di Indonesia dengan budaya sebagai konteks tempat perilaku individual dan sosial tumbuh, berkembang, dan terjadi, memunculkan kebutuhan untuk memahami perilaku tersebut dengan melibatkan cara budaya sebagai konteks memandang dan memaknakan perilaku. Dengan pemahaman tersebut, kami telah menunjukkan bahwa psikoetnografi merupakan suatu pendekatan yang layak digunakan untuk memahami perilaku manusia, khususnya ketika target sasaran adalah sekelompok orang di komunitas tertentu dan hidup dengan budaya tertentu.

Bahwa rentang persoalan psikologis manusia bisa berada pada dirinya sendiri dan bisa terhubung dengan orang-orang lain yang terpapar pada konteks eksternal yang sama, menjadikan asesmen dan intervensi psikologi yang berfokus pada suatu komunitas di ruang natural, sama pentingnya dengan asesmen dan intervensi psikol ogi yang berfokus pada individu di ruang klinik, rumah sakit, maupun sekolah. Hak untuk mendapatkan pendam pingan dan layanan psikologi tidak hanya dimiliki oleh mereka yang mampu membeli layanannya di institusiinstitusi tertentu, melainkan milik semua orang bahkan termasuk mereka yang tidak berada di institusi manapun dan hanya berada di komunitas tempat mereka menjalani hidupnya. Psikoetnografi serta asesmen dan intervensi psikologi di arena komunitas ini, merupakan respon psikolog untuk mengisi ruang kebutuhan itu, yaitu kebutuhan akan layanan psikologi bagi semua orang di Indonesia.

\section{Keterbatasan dan saran}

Penelitian ini hendaknya dilihat sebagai penelitian pemula yang dilakukan untuk mencoba merintis kodifikasi alat kerja psikolog di arena komunitas, sebagai suatu syarat untuk mendapatkan pengakuan akan "ada"nya suatu cabang psikologi tertentu yang membedakannya dengan cabang psikologi lainnya. Belum ada panduan baku yang bisa digunakan untuk menyajikan laporan asesmen psikologi di ranah keprofesian psikolog komunitas ini sebagaimana panduan baku yang dimiliki oleh cabang keprofesian psikologi lain yang sudah mapan. Riset perdana ini mengandalkan cerita dari para praktisi psikolog komunitas yang telah melakukan kerja profesinya selama bertahun-tahun melalui kehadiran mereka di kampus Fakultas Psikologi Unpad maupun kunjungan lapangan para mahasiswa partisipan riset di lokasi tempat mereka bekerja.

\section{Daftar Pustaka}

APA. (2020, July 8). Home//Publications and Databases//Journals//Psychological

Assessment. Diunduh dari https://www.apa.org/pubs/journals/pas/ 
APA. (2020, July 8). Publication \& Databases. Diunduh dari

https://www.apa.org/pubs/search?query=e thnography

APA. (2020, July 8). Publications \& Databases. Diunduh dari https://www.apa.org/pubs/search?query=e thnography

Barre, W. (1955). PSYCHOETHNOGRAPHY: La Psychologie Ethnique. American Anthropologist, 57(1), 174-175. https://doi.org/10.1525/aa.1955.57.1.02a0 0490

Bartholomew, T. T., \& Brown, J. R. (2019). Entering the ethnographic mind: A grounded theory of using ethnography in psychol ogical research. Qualitative Research in Psychology, 1-30. https://doi.org/10.1080/14780887.2019.1 604927

Belsiyal, X. (2016). Ethno psychology and its Application - Review. Research Journal of Humanities and Social Sciences, 7(4), 241$249 . \quad$ https://doi.org/10.5958/23215828.2016.00051.6

Biddle, K. G., \& Locke, K. D. (2007). Composing Qualitative Research. California, USA: SAGE Publications.

https://doi.org/10.4135/9781412983709

Budiharto, S., Himam, F., Riyono, B., \& Fahmi, A. (2019, 12). Membangun Konsep Organisasi Autentik: Kajian Meta-Etnografi. Buletin Psikologi, 27(2), 159-172. https://doi.org/10.22146/buletinpsikologi. 43267

Cargill, K. (2006). Off The Couch and Onto The Streets: Toward An Ethnographic Psychoanalysis. Psychoanalysis, Culture and Society, 11(1), 99-105.

https://doi.org/10.1057/palgrave.pcs. 2100 073

Case, A. D., Todd, N. R., \& Kral, M. J. (2014, April 15). Ethnography in Community Psychology: Promises and Tensions. American Journal of Community Psychology, 54(1-2), 60-71. https://doi.org/10.1007/s10464-014-96480

Department of Communication and New Media, Faculty of Arts and Social Sciences, National University of Singapore. (2016). CultureCentered Method: The nuts and bolts of cocreating communication infrastructures of listening in communities. CARE: White Paper Series, 2, hal. 1-18.

Gergen, K. J. (2014). Pursuing excellence in qualitative inquiry. Qualitative Psychology, I(1), 49-60. https://doi.org/10.1037/qup0000002

Hallett, R. E., \& Barber, K. (2014). Ethnographic Research in a Cyber Era. Journal of Contemporary Ethnography, 43(3), 306-330. https://doi.org/10.1177/08912416134977 49
Hartmann, W., St. Arnault, D., \& Gone, J. (2018). A Return to "The Clinic" for Community Psychology: Lessons from a Clinical Ethnography in Urban American Indian Behavioral Health. American Journal of Community Psychology, 61(1-2), 62-75. https://doi.org/10.1002/ajcp.12212

Hollan, D. (2016). Psychoanalysis and Ethnography. ETHOS, 44(4), 507-521. https://doi.org/10.2478/v10317-0120003-4

Ismail, A., Munsi, H., \& Hans, A. (2019). Online Social Movement: Adopsi Teknologi Informasi dalam Melakukan gerakan Sosial di Indonesia. ETNOSIA: Jurnal Etnografi Indonesia, 4(1), 91-114. https://doi.org/10.31947/etnosia.v4i1.503 9

Josselson, R. (2020, July 7). A Brief History of SQIP. Diunduh dari http://sqip.org/about/a-briefhistory-of-sqip/

Kaur-Gill, S., \& Dutta, M. J. (2017). Digital Ethnography. Dalam J. (. Matthes, The International Encyclopedia ofCommunication Research Methods. John Wiley \& Sons, Inc. https://doi.org/10.1002/9781118901731.i ecrm0271

Kearney, M. H. (2001). Focus on research methods: Levels and Applications of Qualitative Research Evidence. Research in Nursing \& Health, 145-153. https://doi.org/10.1002/nur.1017

Kemendikbud Republik Indonesia. (2019). Kamus Besar Bahasa Indonesia (KBBI), online/daring. Diunduh dari https://kbbi.web.id

Kharel, D. (2015). Visual Ethnography, Thick Description and Cultural Representation. Dhaulagiri Journal of Sociology and Anthropology, 9, 147-160. https://doi.org/10.3126/dsaj.v9i0.14026

Kloos, B., Hill, J., Thomas, E., Wandersman, A., Elias, M. J., \& Dalton, J. H. (2012). Community Psychology: Linking Individuals and Communities (3rd ed.). California: WADsWORTH:CENGAGE Learning.

Lahlou, S., Le Bellu, S., \& Boesen-Mariani, S. (2015). Subjective Evidence Based Ethnography: Method and Applications. Integr Psych Behav, 49(2), 216-238. https://doi.org/10.1007/s12124014=9288-9

Madill, A., \& Gough, B. (2008). Qualitative research and its place in psychological science. Psychological Methods, 13(3), 254-271. https://doi.org/10.1037/a0013220

Marcen, C., Gimeno, F., Gutierrez, H., \& Saenz, A. S. (2013). Ethnography as a Linking Method Between Psychology and Sociology: Research Design. Procedia - Social and Behavioral Sciences. 82, 760-763. 
https://doi.org/10.1016/j.sbspro.2013.06.3 44

Meyer, G. J., Finn, S. E., Eyde, L. D., Kay, G. G., Moreland, K. L., Dies, R. R., . . Reed, G. M. (2001, February). Psychological Testing and Psychological Assessment: A Review of Evidence and Issues. American Psychologist, 56(2), 128-165. https://doi.org/10.1037//0003066X.56.2.128

Moritsugu, J., Vera, E., Wong, F. Y., \& Duffy, K. G. (2016). Community Psychology (5th ed.). New York, USA: Routledge, Taylor and Francis Group.

Naidoo, L. (2012). Ethnography: An Introduction to Definition and Method. An Ethnography of Global Landscapes and Corridors, 1-9. https://doi.org/10.5772/39248

Nerlich, B. (2004). Coming full (hermeneutic) circle: The controversy about psychological methods. Dalam Z. Todd, B. Nerlich, S. McKeown, \& D. D. Clarke, Mixing methods in psychology: The integration of qualitative and quantitave methods in theory and practice. Hove and New York, USA and Canada: Psychology press; Taylor \& Francis Group.

Newman, I., \& Benz, C. R. (1998). Qualitativequantitative research methodology: Exploring the interactive continuum. Illinois, USA: Southern Illinois University Press.

Pink, S., Horst, H., Postill, J., Hjorth, L., Lewis, T., \& Tacchi, J. (2016). Digital Ethnography: Principles and Practice. (j. Seaman, Penyunt) London: SAGE Publication, Ltd.

Schneider, D. (1955). PSYCHOETHNOGRAPHY: Truk: Man in Paradise. Thomas Galdwin and Seymour B. Sarason. American Anthropologist, 57(5), 1098-1101. https://doi.org/10.1525/aa.1955.57.5.02a0 0540

Slay, J. (2007). Naturalistic inquiry in cross-cultural research: A narrative turn. Dalam P. C.
Taylor, \& J. Wallace, Qualitative Research in Postmodern Times. Dordrecht, The Netherlands: Springer.

Sofia, N., \& Prawitasari, J. E. (2016). Subjective wellbeing on javanese peoples that practice pesugihan: An indigenous psychology. The 5th International Congress on Interdisciplinary Behavior and Social Science 2016 (ICIBoS 2016) (hal.12-18). Yogyakarta: CRC Press/Balkema: Taylor \& Francis Group. Diunduh dari http://hdl.handle.net/123456789/7308

Stroebe, W., \& Strack, F. (2014). The alleged crisis and the illusion of exact replication. Perspectives on Psychological Science, 9(1), 59-71.

Thein-Lamelson, S. N. (2015). Grooming and cultural socialization: A mixed method study of caregiving practices in Burma (Myanmar) and the United States. International Joumal of Psychology, 50(1), 37-46. https://doi.org/10.1002/ijop.12119

Wallace, A. F. (1954). PSYCHOETHNOGRAPHY: The Study of Culture at a Distance. Margaret Mead and Rhoda Metraux. American Anthropologist, 56(6), 1142-1145. https://doi.org/10.1525/aa.1954.56.6.02a0 0560

Weidmann, N. B., Baleato, S. B., Hunziker, P., Glatz, E, \& Dimitropoulos, X. (2016). Digital discrimination: Political bias in Internet service provision across ethnic groups. Science, 353(6304), 1151-1155. https://doi.org/10.1126/science.aaf5062

Whiting, J. (1953). Psychoethnography. Growth and Culture, A Photographic Study of Balinese Childhood. Margaret Mead and Frances Cooke MacGregor. American Anthropologist, 55(2), 262-263. https://doi.org/10.1525/aa.1953.55.2.02a0 0240 